УДК 297; 27.

КBT 86.38; 36.37.

DOI 10.33864/MTFZK.2019.27

Francesco ALFIERI*
(Vatican)

\title{
The Example of Common Path to Truth
}

\section{Abstract}

The article is a review for the book of Prof.Dr. Konul Bunyadzade "Wisdom of Love: Rabia al-Adawiyya and Edith Stein". The author of the article notes that the book is very important as a chance to build a solid foundation for an ever greater communion between the two great monotheistic religions, precisely Islam and Christianity and to show how a "common" path of research can be followed. "Love" and "grace" are the benchmarks of this book where Bunyadzade compared the views of Rabia al-Adawiyya and Edith Stein - the true servers of their religions as Islam and Christianity. This book brings us back to the importance of a "community work" that can become a way of life, since the search for "Truth" cannot be conducted in isolation, but it needs the help of many associates in order to be reached. These features and the method of the book make it not only an unicum, but also a novum showing how it is possible to undertake such an itinerary when we let ourselves be guided by "Wisdom". The "Wisdom" is a companion on the road who walks with us silently; only by crossing its silence we can understand how the words that arise from this silence are no longer those that we use in everyday language, but we can hear in it the words rich in meaning. Bunyadzade's merit was that of restoring these "words" through the poetic language of Rabia and that of Edith in his Kreuzeswissenschaft (Scientia crucis), a work that she ended in the silence of the Auschwitz-Birkenau extermination camp.

The author of the article notes that this book "infuses faith into humanity". Moreover, it is also an ethical duty to continue to reflect on what the Author has so

* Prof., Dr., Pontific Lateran University. frafrancescoalfieriofm@ yahoo.it. https://orcid.org/0000-0001-5775-1073. 
Francesco Alfieri. The Example of Common Path to Truth. p. 30-36

generously "returned" to us in a sharing spirit which is also an invitation to communion. Continuing to think is necessary to act thinking.

Keywords: Divine love, Edith Stein, Rabia al-Adawiyya, divine wisdom, "IOther-Divinity", "I-Other-Deity".

The analyzes conducted by Prof. Konul Bunyadzade during these years and merged into the present volume: "Divine and Human Love in Philosophy: (Rabia alAdawiyya (VIII c.) and Edith Stein (XX c.)", are unique for different reasons for the scientific world of the Stein studies. Yet, before analyzing in detail the theoretical scope of some of these reasons, I would like to focus on an aspect that I believe will be useful for the reader who is about to analyze the book and which markedly distinguishes the cut that Bunyadzade wants to give to her investigations: she serves the research to build a solid foundation for an ever greater communion between the two great monotheistic religions, precisely Islamism and Christianity. I intentionally use the verb "to serve" because in our specific case it indicates the author's "putting herself at the service" in her continuous researching, thus becoming a "servant" precisely because she seeks the full sense. Only in this condition the research, the rigorous one, can be a valid instrument that helps us to look beyond to see how the "sacred" comes to meet us while we ourselves are walking a stretch of path. For those like me who have read the work done by the author, it is possible to see how a "common" path of research can be followed. Normally it is customary to talk about the common points, or points of contact, which exist in the two great monotheisms, but these commonplaces are abundantly overcome by the Author, who, instead, operates a radical change: she shows how Rabia al-Adawiyya and Edith Stein - through the direct experience of the "divine" and "human" - can re-create a common path where it is possible to understand how divinity and humanity walk together to merge into mystical experience. The stakes in this book are very high because the "points in common" are radically supplanted by the "common" interest in seeking Truth and, therefore, the sacred. The human being thus becomes a seeker of meaning, since in him there is a trace of the sacred that lives deeply within it.

In this way Bunyadzade performs the juxtaposition of two women who have marked the history of Sufism and Christianity. This approach was made possible because the author has masterfully combined the salient aspects not only of Rabia al- 
Adawiyya, but above all of the phenomenologist Edith Stein, an important member of the phenomenological circle of Göttingen, who became a catholic in 1922 although coming from a Jewish family. Stein's intellectual journey and a first attempt of comparison with Sufism was analyzed by Bunyadzade in an anthology published in Italy in 2014 ${ }^{1}$. This work received the consent of many Catholic figures in the Vatican City because for the first time the figure of Stein was seen in continuity with the "elected women" of the Koran who are called to go all the way to wisdom. Bunyadzade's contribution in the book "Starting again from Edith Stein" represents the first attempt of a "plural thinking". In fact, there are contributions from all Stein specialists from different parts of the world, and along with these the contribution offered by two scholars of Azerbaijan, such as that of the author and of prof. Salahaddin Khalilov $^{2}$. They not only constitute the point of connection between East and West, but also a solid foundation to accomplish together the stretch of road already undertaken.

"Love" and "grace" are the benchmarks of this book from which a reflection on the human being begins, seen in the dual dynamics of the masculine / feminine. The research method used by Bunyadzade is exclusively phenomenological: if the divine frames the entire volume, the human being here assumes the focal point that animates the constant concern of the author of furnishing an investigation that can restore full dignity to it, very often disfigured by the many social and religious conditions. In fact, the human being caught in its uniqueness is always open to relationship: this is one of the theoretical junctions that make this book unique not only from a philosophical, but also from an ethical point of view. Why talk about "relationship" and not "relationships" when referring to the human being? The Author shows in a convincing way that only the term "relationship" is the one that most truthfully renders the action of the human being. This is because it is in a single "relationship"

\footnotetext{
${ }^{1}$ Cfr. BunYadZADE K., La donna come ricercatrice della perfezione. Un possibile approccio allo studio del pensiero di Edith Stein in Azerbaijan, in Ripartire da Edith Stein. La scoperta di alcuni manoscritti inediti (Quaderni per l'Università, 5), P. Manganaro - F. Nodari (eds.), Prefazione di L. Boella, Morcelliana, Brescia 2014, pp. 335-344.

${ }^{2}$ Cfr. KhaliLov S., L'opera «Die Rezeption Edith Steins» apre una nuova stagione di studi in Azerbaijan. Spunti per una fenomenologia della religione, in Ripartire da Edith Stein. La scoperta di alcuni manoscritti inediti (Quaderni per l'Università, 5), P. Manganaro - F. Nodari (eds.), Preface by L. Boella, Morcelliana, Brescia 2014, pp. 323-334.
} 
that the human being lives his relationship with himself, with the divinity and with others. There is therefore a single relationship that is structured in different "degrees". Only in this way the uniqueness of the human being is guaranteed, and his or her action takes on a new qualitative trait since in relation to "I-Other-Deity" the human being is aware that in this triad there is a fusion that must always be safeguarded. Instead, it is often common to experience "relationships" that are most often exclusive: the "I-Other-Divinity" triad contains a fusion that cannot be separated by arbitrary relationships. Hence the ethical living and the value of "tolerance", so acutely analyzed by Bunyadzade, depend on the ability to see in this triad not only the difference but the harmony of differences. It is no coincidence that the human being opens to a first alterity when he decides to live the relationship with his fellows: it is from this first experience of otherness that we discover that there is a much greater Alterity that governs the world. It is therefore not possible to choose to come to the Other in an isolated way excluding the others. Just think, for example, how the vital environment in which Edith Stein's investigations mature has always been the "community" environment.

Every place in her work is full of comparisons, assumptions, references to other authors who, in the spirit of Stein's research, are fundamental along the road that leads to the achievement of truth; the method learned at Husserl's school consisted of a work absolutely alien to forms of pure soliloquy. It is in this direction that Bunyadzade's theoretical framework helps us to understand how "ethical action" springs from community life; precisely of those who feel the responsibility of making the reader grasp that the search for Divinity naturally leads us to set up qualitative relationships aimed at the common good and at safeguarding the dignity of the human being, of any human being. "I-Other-Deity" is an example of how diversity is a source of treasure and cannot be seen as a threat. We might venture to say that the diversity that regulates the world is necessary - I would dare say indispensable - so that every human being can keep his personal individuality in the world of life (Lebenswelt).

The author brings us back to the importance of a "community work" that can become a way of life, since the search for "Truth" cannot be conducted in isolation, but it needs the help of "many" in order to be reached. Only in this way every selfreferential position no longer finds justification because a new dimension opens up 
to us: the "community" (Gemeinschaft). However, it is necessary to be constantly accompanied by an "inner gaze" (first degree of relationship) that knows how to recognize in its own and in the other's singularity the first seed of a greater Alterity. Our otherness, the inner one, enables us to discover the transcendence of the alter ego (second degree of relationship), analogously to the infinite Being. Therefore, in the mutual relationship of community living, the person lives his or her second possibility towards a greater transcendence (third degree of relationship).

All these aspects and the style with which they are analyzed by the author make this book not only a unicum, but also a novum showing how it is possible to undertake such an itinerary when we let ourselves be guided by "Wisdom". The "Wisdom" as a companion on the road who walks with us silently; only by crossing its silence we can understand how the words that arise from this silence are no longer those that we use in everyday language, but we can hear in it words rich in meaning. Bunyadzade's merit was that of restoring these "words" through the poetic language of Rabia and that of Edith in his Kreuzeswissenschaft (Scientia crucis), a work that she ended in the silence of the Auschwitz-Birkenau extermination camp.

It is a great honor for me to express my gratitude to Prof. Konul Bunyadzade for having infused faith in humanity with this book, but it is also an ethical duty to continue to reflect on what the Author has so generously "returned" to us in a sharing spirit which is also an invitation to communion. Continuing to think is necessary to act thinking.

1st January 2018

Passage to the Catholic Church with the Sacrament of Baptism received in Bergzabern on 1st January 1922

\section{Prof.Dr. Françesko Alfieri}

\section{Haqqa aparan ortaq yol nümunosi}

(xülasa)

Məqalə AMEA-nın müxbir üzvü Könül Bünyadzadənin "Eşqin hikməti. Rabiə al-Әdaviyya va Edit Stein" kitabına (Bakl, 2018) yazılmış raydir. Müallif har şeydan avval vurğulayır ki, aparılmış tadqiqatı iki böyük monoteist din, daha daqiq desək, Islam va Xristianlıq arasında daha sıx ünsiyyatin qurulması üçün möhkam taməlin 
yaradılmasında xüsusi əhəmiyyətə malikdir və "ortaq" tədqiqat yolunun çəkilməsinə bir nümunadir. Onun fikrina göra, kitabda Xristianlıq va İslamin görkəmli qadın nümayandalari arasinda aparılan müqayisali təhlil eşq va marhəmətin etalonu hesab edila bilar. Bela ki, bu tədqiqat "barabər işin" ahəmiyyatina doğru geri aparır ki, o bir hayat tarzina çevrila bilar. "Haqqın" axtarışı tacrid olunmuş şəkilda aparıla bilmaz va maqsada çatmaq üçün "çoxlarının" köməyina ehtiyac var. Qeyd edilan keyfiyyatlar va üslub kitabr yalnız unikal (unicum) deyil, həm do yeni edir. O, idara etməyi "Hikmətə" həvala edəndə necə bir yol clzmağın mümkünüyünü göstərir. Müallifin fikrina göra, "Hikmat" sakitca bizimla barabar gedan yol yoldaşı kimidir va yalnız bu sakitliyi pozmaqla biz anlaya bilirik ki, bu sakitlikdən ucalan sözlar bizim gündalik işlatdiyimiz sözlar kimi deyil, biz burada ancaq mana dolu sözlar eşida bilarik. Bünyadzadanin avazsiz xidmati ondadır ki, bu "sözlari" Rabianin poetik dili va Editin artıq Auschwitz-Birkenau habs düşargasinda bitirdiyi "Xaçın elmi" Kreuzeswissenschaft (Scientia crucis) asari vasitasila barpa edir.

Müallif bela hesab edir ki, kitab "başariyyatə iman üfürür." Eyni zamanda, bu həm də davamlı olaraq düşünməyə davat edən bir etik borcdur: Müallif böyük bir səxavatla bizi ruhlarımızın saylarini takrar birlaşdirmaya davat edir. Bu, ham da vahdata bir davatdir. Düşünməkda davam etmək lazımdır ki, düşünə bilak.

Açar sözlor: Illahi eşq, Edith Stein, Rabia al-Odəviyyz, ilahi hikmət, "Mənbaşqast-ilahilik", "Mon-başqast-ilahi Zat".

\title{
Проф. Др. Франческо Альфьери
}

\section{Пример общего пути к Истине}

\author{
(резюме)
}

Статья является отзывом на книгу члена-корреспондента НАНА Кенуль Буньядзаде «Мудрость любви: Рабиа ал-Адавыййа и Эдит Штайн» (Баку, 2018). Автор прежде всего отмечает, что проведенное исследование имеет важное значение как пример более тесного общения между двумя большими монотеистическими религиями, а именно между Исламом и Христианством, и как пример проведения совместного исследования. Он считает, что эталоном книги, в которой проводятся параллели между женщинами-философами, истинныли служителями своей религии, могут выступать «любовь» и «благодать». Это исследование возвращает к мысли о важности «совместной работыл и это может стать образом жизни. Ведь поиск «Истины» не может вестись в одиночку и нуждается в помощи многих. Эти качества и метод, примененный К. Буньядзаде, делает книгу не только уникальной, но и новым феноменом. Книга показывает, как можно совериать такое путешествие, когда мы полностью доверяемся «Мудрости». Ведь «Мудрость» по- 
хожа на молчаливого спутника, и только нарушив это молчание, мы сможем понять, что слова, исходящуие из молчания, не похожи на обычные и мы сможем ульшиать лишь слова, полнье смысла. Неоченимая заслуга Буньядзаде заключается в том, что она восстановливает эти слова посредством поэтического языка Рабийа и произведения Эдит «Наука Kреста»/Kreuzeswissenschaft (Scientia crucis), которое она написала в концентрационном лагере смерти Аушвиц-Биркенау.

Автор считает, что книга «вдувает веру в человечество». В то же время это - этический долг продолжать размыилять над всеобщей духовностью, которую Автор с такой щедростью возвращает нам и что также является приглашением кединению. Ведь чтобы уметь думать необходимо непрерывно думать.

Ключевые слова: божественная любовь, Эдит Штайн, Рабийа ал-Адавиййа, божественная мудрость, «Я-другой-божественност», «Я-другой-божественная Суть». 